\title{
PREGNENOLONE AND PROGESTERONE CONCENTRATIONS IN OVARIAN VENOUS BLOOD OF THE ARTIFICIALLY OVULATED SQUIRREL MONKEY (SAIMIRI SCIUREUS)
}

\author{
A. B. FAJER AND D. BECHINI \\ Department of Physiology, School of Medicine, \\ University of Maryland, Baltimore, Maryland 21201, U.S.A.
}

(Received 13th November 1970)

\begin{abstract}
Summary. Ovulation was induced in sexually immature squirrel monkeys by PMSG-HCG injections and pregnenolone and progesterone concentrations were determined in the ovarian venous blood. Extensive follicular growth does not permit the diagnosis of ovulation without histological examination of the ovaries. Ovulation was followed by extensive luteinization and detectable amounts of pregnenolone and progesterone 2 days after treatment but, by 5 days after treatment, only five out of eleven animals had detectable hormone concentrations. The interstitial tissue is suggested as the source of pregnenolone.
\end{abstract}

\section{INTRODUCTION}

The breeding of the squirrel monkey (Saimiri sciureus) in captivity has met with only partial success. This fact may be related to the scarcity of objective data concerning the reproductive physiology of this New World primate (Beischer \& Furry, 1964; Rosenblum, 1968; Hutchinson, 1970). Because of this, the majority of the animals used in research have been obtained from their natural habitat with all the problems that such supply creates.

Some attempts have been made to obtain ovulation and pregnancy after treatment with exogenous hormones (Bennett, 1967a, b). Following the artificial insemination of three adult monkeys, fertilized eggs were recovered at the twocell stage from the Fallopian tubes of two monkeys and at the two-cell and fourcell stage from the uterus in the third animal (Bennett, 1967b). As in other species, the administration of exogenous gonadotrophins may result in unphysiologically high steroid secretion. In the rat, following PMSG-HCG treatment, not only is the progesterone concentration elevated to levels found only in pregnant rats (Fajer, 1968) but oestrogen secretion may be abnormally high as deciduomata formation is inhibited (Guillet \& Rennels, 1964). In man, artificial induction of ovulation very often results in over-stimulation with ovarian enlargement and cyst formation (Rosemberg, 1968).

This paper describes the pregnenolone ( $3 \beta$-hydroxypregn-5-en-20-one) and progesterone (pregn-4-ene-3,20-dione) secretion by artificially stimulated ovaries 
of immature animals as part of a larger project on the ovarian physiology in the squirrel monkey.

\section{MATERIALS AND METHODS}

\section{Animals}

Twenty immature female squirrel monkeys of Peruvian and Brazilian phenotype (Hill, 1960) with an average weight of $634 \mathrm{~g}$ were used. The animals were obtained from commercial suppliers and were acclimatized to laboratory conditions for at least 1 week before treatment. Purina monkey chow and water were always available and a vitamin supplement was administered orally, twice weekly.

\section{Treatment}

Ovulation was induced by the intramuscular administration twice daily for 9 days, of 50 i.u. of PMSG (Equinex, Ayerst Labs), supplemented during Days 6 to 9 by twice daily intramuscular injections of 250 i.u. of HCG (Follutein, E. R. Squibb). The animals were killed 2 or 5 days after the last injection. Three animals were injected with an isotonic saline solution and used as controls.

\section{Ovarian venous blood collection}

The animals were anaesthetized with $35 \mathrm{mg} / \mathrm{kg}$ body wt of sodium pentobarbital (Nembutal, Abbott) administered intramuscularly.

The left femoral vein was cannulated for saline or drug administration. Rectal temperatures were continuously monitored with an electronic thermometer and maintained between 37 and $39^{\circ} \mathrm{C}$ with the help of an electric heating pad.

After heparinization (heparin sodium, U.S.P. grade, Fisher Scientific G. 5000 i.u./kg body wt, intravenously), blood was collected separately from each ovary directly from the ovarian vein using an appropriate polyethylene cannula. The collection time varied from 20 to $30 \mathrm{~min}$ for each sample. Blood samples were collected in tubes packed in crushed ice and later frozen at $-20^{\circ} \mathrm{C}$. Ovarian blood flow varied between 0.05 and $0.12 \mathrm{ml} / \mathrm{min} /$ ovary 2 days after treatment and between 0.04 and $0.06 \mathrm{ml} / \mathrm{min} /$ ovary 5 days after treatment.

Before vein cannulation, the ovaries were examined for sites of ovulation. At the end of the experiment, they were removed, weighed to the nearest $\mathrm{mg}$ and fixed for histological preparation.

\section{Extraction of steroids}

The samples were thawed and diluted to $10 \mathrm{ml}$ with distilled water. To each sample were added $0.25 \mathrm{ml}$ of $20 \%$ aqueous solution of $\mathrm{NaOH}$ and 4000 d/min $\left[1,2-{ }^{3} \mathrm{H}\right]$ progesterone (NET-208-S.A. $33.5 \mathrm{Ci} / \mathrm{mmole}$, lot 400-054; New England Corp).

The samples were extracted three times with a total of 10 vol. of ethyl ether. The total extract was washed with a $0 \cdot 1$-vol. of $1 \%$ sodium carbonate solution, then with a $0 \cdot 1$-vol. of $1 \%$ acetic acid and 0.1 vol. of distilled water until neutral. After the addition of $1 \mathrm{ml}$ of ethanol, the ether was evaporated under 
reduced pressure in a rotary evaporator. The residue was partitioned four times $(\mathrm{v} / \mathrm{v})$ between petroleum ether (b.p. 30 to $60^{\circ} \mathrm{C}$ ) and methanol:water $(7: 3, v / v)$. The aqueous methanol was evaporated to dryness with additional ethanol.

\section{Thin-layer chromatography}

The residue was spotted on silica gel plates (E. Merck, TLC-silica gel F-254, $0.25 \mathrm{~mm}$ thick) pre-washed by ascending chromatography for $24 \mathrm{hr}$ with chloroform-methanol, methanol and ethyl ether. The chromatographic systems used were: A-benzene: ether, $1: 1(\mathrm{v} / \mathrm{v}) ; \mathrm{B}-$ benzene: ether, $3: 1(\mathrm{v} / \mathrm{v})$.

After development in System A, areas corresponding to authentic progesterone and pregnenolone were extracted in small funnels with $2 \mathrm{ml}$ of a methanolether mixture $(1: 1)$, and the solvents were evaporated under nitrogen. The progesterone and pregnenolone samples were acetylated with acetic anhydridepyridine $(1: 2)$ for $18 \mathrm{hr}$ in the dark. After the addition of methanol, the reagents were evaporated and the residue rechromatographed on silica gel plates in System B.

The areas corresponding to progesterone and pregnenolone acetate were eluted and dried. The recoveries varied between 40 and $55 \%$.

\section{Gas liquid chromatograph $(G L C)$}

After the first and the second chromatograms, steroid identity was further ascertained by GLC in a Model $402 \mathrm{~F} \& \mathrm{M}$ gas chromatograph using a 4-foot column of $3.8 \%$ SE-30 on Diatoport-S and a 6 -foot column of QF-1 on Gaschrom $Q$ (Applied Science Lab.).

Retention times were compared to that of authentic pregnenolone, progesterone and pregnenolone acetate, where necessary. Cholestane was used as an internal standard.

\section{Quantitative determination of pregnenolone and progesterone}

For routine purposes, progesterone and pregnenolone were eluted simultaneously after the first TLC development in System A and quantified using GLC with an SE-30 column against an internal standard of $11 \beta$-hydroxyprogesterone (Heap, Holzbauer \& Newport, 1966; Fajer \& Holzbauer, 1968).

Samples of peripheral blood, of equal volume, when submitted to the same procedures showed no detectable peaks of pregnenolone or progesterone.

Results were adjusted to $100 \%$ recovery after determination of the radioactivity in an aliquot of the sample before GLC. Radioactivity was determined in toluene (50 mg/litre of POPOP and $4 \mathrm{mg} /$ litre of PPO) using a Nuclear Chicago Liquid Scintillation counter model 720 with an efficiency of $30 \%$ for ${ }^{3} \mathrm{H}$.

\section{RESULTS}

There was a significant increase in the ovarian and uterine weights in sixteen of the seventeen animals treated with PMSG and HGG (Tables 1 and 2). All organ weights fell within the same range regardless of the day of observation. In the 
Table 1

ORGAN WEIGHTS OF ANIMALS 2 DAYS AFTER TREATMENT

\begin{tabular}{|c|c|c|c|c|c|c|c|}
\hline \multirow{2}{*}{ Animal } & \multirow{2}{*}{$\begin{array}{l}\text { Animal } \\
\text { wot }(g)\end{array}$} & \multirow{2}{*}{$\begin{array}{c}U_{\text {terus }} \\
w t(m g)\end{array}$} & \multirow{2}{*}{$\begin{array}{c}\text { Left } \\
\text { ovary } \\
(\mathrm{mg})\end{array}$} & \multirow{2}{*}{$\begin{array}{l}\text { Right } \\
\text { ovary } \\
(\mathrm{mg})\end{array}$} & \multirow{2}{*}{$\begin{array}{c}\text { Uterus } \\
(m g / k g \\
\text { body wt })\end{array}$} & \multicolumn{2}{|c|}{ Ovary (mg/kg body wt) } \\
\hline & & & & & & Left & Right \\
\hline \multicolumn{8}{|c|}{ (a) Pregnenolone and progesterone detectable } \\
\hline $\begin{array}{l}A \\
G \\
H \\
P \\
\mathbf{Q}\end{array}$ & $\begin{array}{l}625 \\
680 \\
710 \\
730 \\
570\end{array}$ & $\begin{array}{c}\text { NA* } \\
2140 \\
2960 \\
1270 \\
1040\end{array}$ & $\begin{array}{r}430 \\
424 \\
820 \\
545 \\
1374\end{array}$ & $\begin{array}{r}600 \\
742 \\
1446 \\
1040 \\
850\end{array}$ & $\begin{array}{c}\text { NA } \\
3147 \\
4169 \\
1740 \\
1825\end{array}$ & $\begin{array}{r}688 \\
624 \\
1155 \\
747 \\
2411\end{array}$ & $\begin{array}{r}960 \\
1091 \\
2037 \\
1425 \\
1491\end{array}$ \\
\hline $\begin{array}{l}\text { Mean } \\
\text { S.E. } \dagger\end{array}$ & $\begin{array}{r}663 \\
29\end{array}$ & $\begin{array}{r}1853 \\
438\end{array}$ & $\begin{array}{l}719 \\
178\end{array}$ & $\begin{array}{l}936 \\
146\end{array}$ & $\begin{array}{r}2720 \\
581\end{array}$ & $\begin{array}{r}1125 \\
335\end{array}$ & $\begin{array}{r}1401 \\
188\end{array}$ \\
\hline \multicolumn{8}{|c|}{ (b) Pregnenolone and progesterone not detectable } \\
\hline B & 585 & NA & 140 & 240 & NA & 239 & 410 \\
\hline \multicolumn{8}{|c|}{ (c) Control animals (mean of data from three monkeys) } \\
\hline $\begin{array}{l}\text { Mean } \\
\text { S.E. }\end{array}$ & $\begin{array}{r}710 \\
70\end{array}$ & $\begin{array}{l}620 \\
124\end{array}$ & $\begin{array}{r}120 \\
9\end{array}$ & $\begin{array}{r}110 \\
17\end{array}$ & $\begin{array}{r}856 \\
95\end{array}$ & $\begin{array}{r}169 \\
7\end{array}$ & $\begin{array}{r}155 \\
17\end{array}$ \\
\hline \multicolumn{5}{|c|}{$t$ test, $\$$ Group (a) versus Group (c) } & $P=0.05$ & $P<0.02$ & $P<0.002$ \\
\hline
\end{tabular}

* NA-Not available.

$\dagger$ S.E. - Standard error of the mean.

$\ddagger$ Values corrected for unequal variances (Bailey, 1959).

TABLE 2

ORGAN WEIGHTS* OF ANIMALS 5 DAYS AFTER TREATMENT

\begin{tabular}{|c|c|c|c|c|c|c|c|}
\hline \multirow{2}{*}{ Animal } & \multirow{2}{*}{$\begin{array}{l}\text { Animal } \\
\text { wt }(g)\end{array}$} & \multirow{2}{*}{$\begin{array}{c}\text { Uterus } \\
w t(m g)\end{array}$} & \multirow{2}{*}{$\begin{array}{c}\text { Left } \\
\text { ovary } \\
\text { (mg) }\end{array}$} & \multirow{2}{*}{$\begin{array}{l}\text { Right } \\
\text { ovary } \\
\text { (mg) }\end{array}$} & \multirow{2}{*}{$\begin{array}{c}\text { Uterus } \\
(m g / k g \\
\text { body wt) }\end{array}$} & \multicolumn{2}{|c|}{ Ovary (mg/kg body wt) } \\
\hline & & & & & & Left & Right \\
\hline \multicolumn{8}{|c|}{ (a) Pregnenolone and progesterone detectable } \\
\hline $\begin{array}{l}\mathrm{G} \\
\mathrm{K} \\
\mathrm{L} \\
\mathrm{M} \\
\mathrm{O}\end{array}$ & $\begin{array}{l}620 \\
680 \\
780 \\
700 \\
610\end{array}$ & $\begin{array}{l}3350 \\
1960 \\
1680 \\
2120 \\
1770\end{array}$ & $\begin{array}{r}1140 \\
1026 \\
1216 \\
712 \\
745\end{array}$ & $\begin{array}{r}1050 \\
714 \\
896 \\
1544 \\
404\end{array}$ & $\begin{array}{l}5404 \\
2882 \\
2154 \\
3029 \\
2902\end{array}$ & $\begin{array}{l}2323 \\
1509 \\
1559 \\
1017 \\
1221\end{array}$ & $\begin{array}{r}1694 \\
1050 \\
1149 \\
2206 \\
662\end{array}$ \\
\hline $\begin{array}{l}\text { Mean } \\
\text { S.E. } \dagger\end{array}$ & $\begin{array}{r}678 \\
31\end{array}$ & $\begin{array}{r}2176 \\
303\end{array}$ & $\begin{array}{l}968 \\
102\end{array}$ & $\begin{array}{l}922 \\
189\end{array}$ & $\begin{array}{r}3274 \\
554\end{array}$ & $\begin{array}{r}1526 \\
222\end{array}$ & $\begin{array}{r}1352 \\
270\end{array}$ \\
\hline \multicolumn{8}{|c|}{ (b) Pregnenolone and progesterone not detectable } \\
\hline $\begin{array}{l}\text { D } \\
\text { I } \\
\text { J } \\
\text { N } \\
\text { R } \\
\text { S }\end{array}$ & $\begin{array}{l}630 \\
800 \\
660 \\
650 \\
590 \\
760\end{array}$ & $\begin{array}{r}1000 \\
2650 \\
1780 \\
2470 \\
500 \\
1910\end{array}$ & $\begin{array}{r}882 \\
102 \\
1060 \\
674 \\
359 \\
359\end{array}$ & $\begin{array}{r}1030 \\
274 \\
1080 \\
610 \\
327 \\
759\end{array}$ & $\begin{array}{r}1587 \\
3313 \\
2697 \\
3800 \\
847 \\
2513\end{array}$ & $\begin{array}{r}1400 \\
128 \\
1606 \\
1037 \\
608 \\
839\end{array}$ & $\begin{array}{r}1635 \\
343 \\
1636 \\
938 \\
554 \\
999\end{array}$ \\
\hline $\begin{array}{l}\text { Mean } \\
\text { S.E. }\end{array}$ & $\begin{array}{r}682 \\
33\end{array}$ & $\begin{array}{r}1719 \\
339\end{array}$ & $\begin{array}{l}619 \\
148\end{array}$ & $\begin{array}{l}680 \\
341\end{array}$ & $\begin{array}{r}2460 \\
445\end{array}$ & $\begin{array}{l}936 \\
219\end{array}$ & $\begin{array}{r}1018 \\
219\end{array}$ \\
\hline
\end{tabular}

$t$ test+

Group (a+b) versus Group (c) of Table 1 (untreated) $\quad P<0.001 \quad P<0.001 \quad P<0.001$

* Controls in Table 1, Sub-group (c).

$\dagger$ S.E.-Standard error of the mean.

$\ddagger$ Corrected for unequal variances. Although the means of Sub-group (a) and (b) appear to be different, the equality cannot be statistically rejected. 
5-day group, no difference was seen between the organ weights of animals in which steroids were detected and those in which they were not detected (Table 2).

Only two out of six animals observed on Day 2 showed macroscopic signs of ovulation, while six out of eleven animals observed on Day 5 had ovulation sites. However, on histological examination, with one exception (Animal B, Table 1), all animals had ovulated and luteinization could be observed (Pl. 1, Figs. 1 and 2). The negative animal had a distinctly smaller ovary than any of the other animals of the same group.

Pregnenolone and progesterone were easily detectable in the ovarian

TABLE 3

PREGNENOLONE AND PROGESTERONE SECRETION 2 DAYS AFTER TREATMENT

\begin{tabular}{|c|c|c|c|c|c|c|c|c|}
\hline \multirow{3}{*}{ Animal } & \multicolumn{4}{|c|}{ Pregnenolone $(\mu g)$} & \multicolumn{4}{|c|}{ Progesterone $(\mu \mathrm{g})$} \\
\hline & \multicolumn{2}{|c|}{ Left ovary } & \multicolumn{2}{|c|}{ Right ovary } & \multicolumn{2}{|c|}{ Left ovary } & \multicolumn{2}{|c|}{ Right ovary } \\
\hline & Per $m l$ & Per hr & Per $m l$ & Per hr & Per $m l$ & Per hr & Per $m l$ & Per hr \\
\hline $\begin{array}{l}A \\
G \\
H \\
P \\
Q\end{array}$ & $\begin{array}{l}0.35 \\
0.16 \\
0.30 \\
0.21 \\
0.48\end{array}$ & $\begin{array}{l}1 \cdot 70 \\
0.57 \\
1.60 \\
1.50 \\
4.60\end{array}$ & $\begin{array}{l}0.14 \\
\text { NA* } \\
\text { NA } \\
0.14 \\
0.56\end{array}$ & $\begin{array}{l}1 \cdot 10 \\
\text { NA } \\
\text { NA } \\
0 \cdot 74 \\
4.49\end{array}$ & $\begin{array}{l}0.73 \\
1.06 \\
1.17 \\
0.31 \\
0.59\end{array}$ & $\begin{array}{l}3 \cdot 40 \\
4 \cdot 00 \\
6 \cdot 20 \\
2 \cdot 20 \\
6 \cdot 10\end{array}$ & $\begin{array}{l}0.41 \\
\text { NA } \\
\text { NA } \\
0.06 \\
0.15\end{array}$ & $\begin{array}{l}3.30 \\
\text { NA } \\
\text { NA } \\
0.36 \\
1.20\end{array}$ \\
\hline $\begin{array}{l}\text { Mean } \\
\text { S.E. } \dagger\end{array}$ & $\begin{array}{l}0.31 \\
0.06\end{array}$ & $\begin{array}{l}1.99 \\
0.68\end{array}$ & $\begin{array}{l}0.28 \\
0.14\end{array}$ & $\begin{array}{l}2 \cdot 11 \\
1 \cdot 19\end{array}$ & $\begin{array}{l}0.77 \\
0.16\end{array}$ & $\begin{array}{l}4.38 \\
0.78\end{array}$ & $\begin{array}{l}0.21 \\
0.11\end{array}$ & $\begin{array}{l}1.62 \\
0.87\end{array}$ \\
\hline
\end{tabular}

* NA-Not available.

$\dagger$ S.E.-Standard error of the mean.

TABLE 4

PREGNENOLONE AND PROGESTERONE SEGRETION 5 DAYS AFTER TREATMENT

\begin{tabular}{|c|c|c|c|c|c|c|c|c|}
\hline \multirow{3}{*}{ Animal } & \multicolumn{4}{|c|}{ Pregnenolone $(\mu \mathrm{g})$} & \multicolumn{4}{|c|}{ Progesterone $(\mu g)$} \\
\hline & \multicolumn{2}{|c|}{ Left ovary } & \multicolumn{2}{|c|}{ Right ovary } & \multicolumn{2}{|c|}{ Left ovary } & \multicolumn{2}{|c|}{ Right ovary } \\
\hline & Per ml & $P e r h r$ & Per $m l$ & Per hr & Per $m l$ & Per hr & Per ml & Per $h r$ \\
\hline $\begin{array}{l}\mathrm{C} \\
\mathbf{K} \\
\mathbf{L} \\
\mathbf{M} \\
\mathrm{O}\end{array}$ & $\begin{array}{l}1.56 \\
0.08 \\
0.64 \\
0.14 \\
1.44\end{array}$ & $\begin{array}{l}7.80 \\
0.38 \\
1.83 \\
0.71 \\
4.60\end{array}$ & $\begin{array}{l}2.57 \\
0.11 \\
0.08 \\
0.03 \\
0.00\end{array}$ & $\begin{array}{l}9.80 \\
0.30 \\
0.25 \\
0.11 \\
0.00\end{array}$ & $\begin{array}{l}4.56 \\
0.10 \\
0.42 \\
0.11 \\
0.84\end{array}$ & $\begin{array}{r}22.80 \\
0.47 \\
1.25 \\
0.53 \\
2.70\end{array}$ & $\begin{array}{l}4.78 \\
0.21 \\
0.09 \\
0.03 \\
0.00\end{array}$ & $\begin{array}{r}22.00 \\
0.60 \\
0.29 \\
0.11 \\
0.00\end{array}$ \\
\hline $\begin{array}{l}\text { Mean } \\
\text { S.E.* }\end{array}$ & $\begin{array}{l}0.77 \\
0.31\end{array}$ & $\begin{array}{l}3.08 \\
1.39\end{array}$ & $\begin{array}{l}0.56 \\
0.50\end{array}$ & $\begin{array}{l}2.09 \\
1.93\end{array}$ & $\begin{array}{l}1.90 \\
0.85\end{array}$ & $\begin{array}{l}5 \cdot 55 \\
4 \cdot 33\end{array}$ & $\begin{array}{l}1.02 \\
0.95\end{array}$ & $\begin{array}{l}4 \cdot 60 \\
4 \cdot 35\end{array}$ \\
\hline
\end{tabular}

* S.E.-Standard error of the mean.

venous blood of animals cannulated on Day 2. The average progesterone secretion was $0.77 \mu \mathrm{g} / \mathrm{ml}$ of ovarian blood, or $4.38 \mu \mathrm{g} / \mathrm{hr} / \mathrm{left}$ ovary. The range of these values was wide: 0.31 to $1.17 \mu \mathrm{g} / \mathrm{ml}$, and 2.2 to $6.2 \mu \mathrm{g} / \mathrm{hr} / \mathrm{left}$ ovary. Pregnenolone was present in lower concentrations with an average of 0.30 $\mu \mathrm{g} / \mathrm{ml}$ (range 0.16 to 0.48 ) and $1.99 \mu \mathrm{g} / \mathrm{hr} /$ left ovary (range 0.57 to 4.60 , Table 3).

Five days after the termination of treatment, only five out of eleven animals that had ovulated had detectable progesterone or pregnenolone in their ovarian blood (Table 4). Animal G (Table 4) had the highest values found in 
this series of experiments, the ovary having a significantly higher degree of luteinization. Otherwise no histological differences could be observed between 'secretors' and 'non-secretors'. In general, the concentrations of progesterone found in this 5-day group tended to be lower than those of the previous group (Day 2). Excluding Animal C, the range of progesterone secretion was 0.10 to $0.84 \mu \mathrm{g} / \mathrm{ml}$ or 0.47 to $2.7 \mu \mathrm{g} / \mathrm{hr} /$ left ovary. The values for pregnenolone also show a similar decline in concentration and degree of variability (Table 4).

\section{DISGUSSION}

The results of this study may assist in understanding the difficulties encountered in obtaining successful pregnancy in animals treated with PMSG and HCG (Bennett, 1967b). The treatment used in our study was effective in inducing ovulation in sixteen out of seventeen treated animals, confirming the earlier observations on a smaller group of animals by Bennett (1967a). However, only in eight animals could ovulation have been diagnosed by macroscopic examination of the ovary. Ovulation may be spread over a relatively long period of time (Dukelow, 1970), and the macroscopic signs of ovulation may disappear more rapidly in some animals than in others. Another possibility is that the extensive development of the follicles may not permit one to observe the developing corpora lutea by simple examination of the ovarian surface. Histological examination is then necessary for confirmation of ovulation and luteinization.

The treatment used in this study induced a marked growth of the ovaries (Tables 1 and 2). This growth was mainly due to extensive follicular development. The growth of the uterus would indicate that during the treatment, oestrogens were secreted as suggested by Bennett (1967b).

Extensive luteinization was evident in all animals, the antrum still being present in most of the developing corpora lutea, due to the large dimensions of the collapsed follicles. These luteinized ovaries were found to secrete progesterone and pregnenolone. Progesterone is the characteristic steroid of the corpus luteum; but pregnenolone, in the amounts found, is not a common steroid of ovarian venous blood (Dorfman \& Ungar, 1965). However, pregnenolone has recently been described in rat ovarian venous blood during the oestrous cycle (Fajer \& Holzbauer, 1968), and in hamster ovarian blood during pregnancy and lactation (Fajer, 1970). In the hamster, the suggested origin of pregnenolone is the ovarian interstitial tissue as there are no antral follicles or corpora lutea during lactation. At present, there are no data to extend this hypothesis to the squirrel monkey; however, New World monkeys (Dempsey, 1939) have a characteristically conspicuous interstitial gland (PI. 1, Figs. 3 and 4).

The wide range of the values found for progesterone and pregnenolone suggests that ovarian secretion falls rapidly after the cessation of gonadotrophin treatment. This is supported by the finding that all five animals that ovulated had detectable steroids on Day 2 but that only five out of eleven had detectable steroids on Day 5 after ovulation. This being the case, progesterone is not present to balance the high oestrogen secretion and implantation and pregnancy cannot occur. 

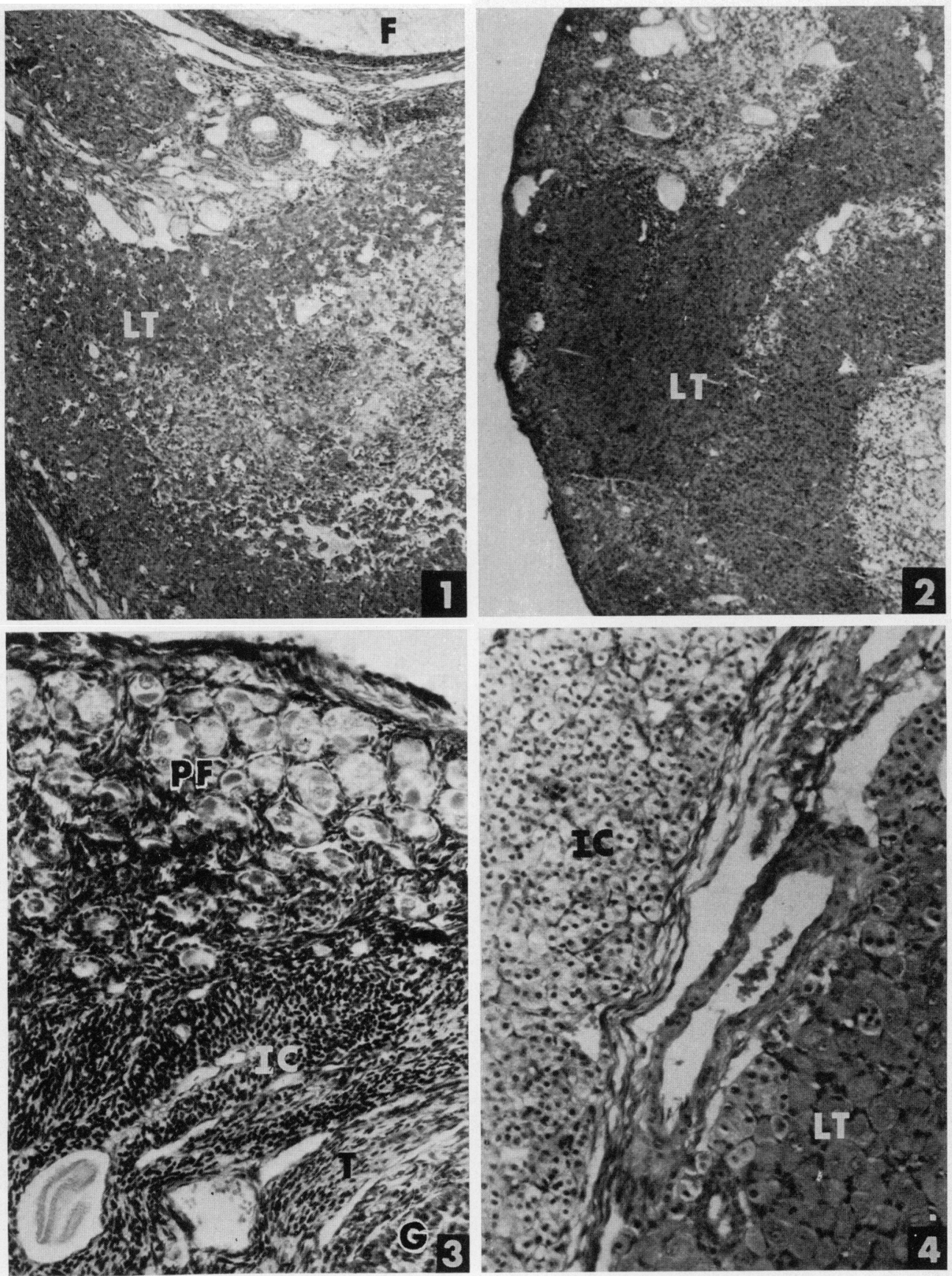

Hatmatoxylin and eosin staned sections of saries of Samiri crimens.

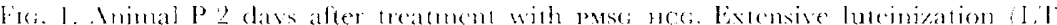
$\times 84$

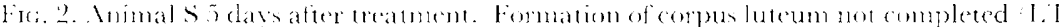
$\times 84$

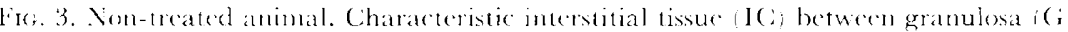
and these (T) of a folliele and the primordial follicles $\mathrm{PF} \times 240$.

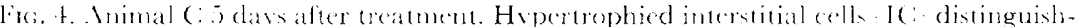

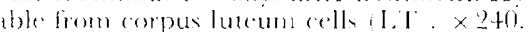


Further studies are now in progress to establish levels of exogenous gonadotrophins which are capable of producing a more balanced ovarian growth and hormonal production capable of supporting pregnancy.

\section{AGKNOWLEDGMENTS}

We are grateful to Mrs Christina Wong and Mr J. Sylvester for their technical assistance and to Ayerst Laboratories Inc., New York, N.Y., for their donation of Equinex.

This work was supported by grants from the National Science Foundation (GB-13794) and the National Institutes of Health (USPHS-GM1075-08).

\section{REFERENCES}

BaILey, N. T. J. (1959) Statistical methods in biology. English Universities Press, London.

BeIsGher, D. E. \& FurRy, D. E. (1964) Saimiri sciureus as an experimental animal. Anat. Rec. 148, 615.

BenNetT, J. P. (1967a) The induction of ovulation in the squirrel monkey (Saimiri sciureus) with pregnant mare serum (PMS) and human chorionic gonadotrophin (HCG). F. Reprod. Fert. 13, 357.

BenNetT, J. P. (1967b) Artificial insemination of the squirrel monkey. F. Endocr. 37, 473.

Dempsey, E. W. (1939) The reproductive cycle of New World monkeys. Am. F. Anat. 64, 381.

Dorfman, R. I. \& Ungar, F. (1965) Metabolism of steroid hormones, p. 52. Academic Press, New York.

DukELOW, W. R. (1970) Induction and timing of single and multiple ovulations in the squirrel monkey (Saimiri sciureus). 7. Reprod. Fert. 22, 303.

FAjer, A. B. (1968) Progestins secretion by artificially luteinized ovaries in normal and hypophysectomized rats. Excerpta med. int. Congr. Ser. 157, 83.

FAJER, A. B. (1970) Loci of action of prolactin and luteinizing hormone in the hamster ovary during lactation: the interstitial tissue. Symposia of the VIIth Pan-American Congress of Endocrinology, S. Paulo, August 1970.

Fajer, A. B. \& Holzbauer, M. (1968) Pregnenolone, progesterone and 20-dihydro progesterone in rat ovarian blood and ovaries during the estrous cycle. F. Physiol., Lond. 196, 99P.

Guillet, G. G. \& Rennels, E. G. (1964) The experimental production of deciduomata in immature rats. Tex. Rep. Biol. Med. 22, 87.

Heap, R. B., Holzbauer, M. \& Newport, H. M. (1966) Adrenal secretion of $\mathrm{C}_{19}$ and $\mathrm{C}_{21}$ steroids before and after hypophysectomy in the pig and the dog. F. Endocr. 36, 159.

HiLl, W. C. D. (1960) Primates. Comparative anatomy and taxonomy, Vol. IV, p. 250. Edinburgh University Press.

Hutchinson, T. G. (1970) Vaginal cytology and reproduction in the squirrel monkey (Saimiri sciureus). Folia primat. 12, 212.

Rosemberg, E. (1968) Gonadotrophin therapy. In: Gonadotrophins, Chap. 6, p. 425. Proceedings of the Workshop Conference, Vista Hermosa, Mexico. Ed. E. Rosemberg. Geron X, Altos, Galif.

Rosenblum, L. A. (1968) Some aspects of female reproductive physiology. In: The Squirrel Monkey, p. 147. Eds. L. A. Rosenblum and R. W. Cooper. Academic Press, New York. 